\title{
Role and Mechanisms of Actions of Thyroid Hormone on the Skeletal Development
}

\author{
Ha-Young Kim ${ }^{1,2,3}$, Subburaman Mohan ${ }^{1,2 *}$
}

${ }^{1}$ Musculoskeletal Disease Center, Loma Linda VA HealthCare System, Loma Linda, CA 92357, USA; '2Departments of Medicine, Loma Linda University, Loma Linda, CA 92354, USA; 3Division of Endocrinology, Department of Internal Medicine, Wonkwang University Sanbon Hospital, Gunpo, Gyeonggi, Korea

The importance of the thyroid hormone axis in the regulation of skeletal growth and maintenance has been well established from clinical studies involving patients with mutations in proteins that regulate synthesis and/or actions of thyroid hormone. Data from genetic mouse models involving disruption and overexpression of components of the thyroid hormone axis also provide direct support for a key role for thyroid hormone in the regulation of bone metabolism. Thyroid hormone regulates proliferation and/or differentiated actions of multiple cell types in bone including chondrocytes, osteoblasts and osteoclasts. Thyroid hormone effects on the target cells are mediated via ligand-inducible nuclear receptors/transcription factors, thyroid hormone receptor (TR) a and $\beta$, of which TRa seems to be critically important in regulating bone cell functions. In terms of mechanisms for thyroid hormone action, studies suggest that thyroid hormone regulates a number of key growth factor signaling pathways including insulin-like growth factor-I, parathyroid hormone related protein, fibroblast growth factor, Indian hedgehog and Wnt to influence skeletal growth. In this review we describe findings from various genetic mouse models and clinical mutations of thyroid hormone signaling related mutations in humans that pertain to the role and mechanism of action of thyroid hormone in the regulation of skeletal growth and maintenance.

Keywords: thyroid hormone; bone; cartilage; growth factors; bone cells

Bone Research (2013) 2: 146-161. doi: 10.4248/BR201302004

\section{Introduction}

Thyroid hormone $(\mathrm{TH})$ plays an important role in nomal endochondral ossification and is essential for skeletal development, linear growth, maintenance of bone mass, and efficient fracture healing (1). Juvenile hypothyroidism causes growth arrest with delayed bone formation and mineralization, and $\mathrm{T} 4$ replacement induces rapid catch-up growth (2). By contrast, childhood thyrotoxicosis accelerates bone formation with premature closure of the growth plates and skull sutures, leading to short stature and craniosynostosis (3). Although there is

*Correspondence: Subburaman Mohan E-mail: Subburaman.Mohan@va.gov Tel: 909-825-7084 (ext 2932); Fax: 909-796-1680 Received 13 March 2013; Accepted 28 April 2013 considerable evidence regarding the importance of $\mathrm{TH}$ in skeletal development, the molecular mechanisms of TH action in bone are poorly understood. In this chapter, we discuss regulation and mechanisms of action of $\mathrm{TH}$ during skeletal development with partic ula remphasison areas in which recent advances have been made.

\section{Physiology of $\mathrm{TH}$ : Regulation, metabolism and $\mathrm{TH}$ receptor}

\section{Regulation}

Systemic $\mathrm{TH}$ levels are maintained by the classical negative feedback loop involving the hypothalamus-pituitary-thyroid (HPT) axis (Figure 1). Thyrotropin releasing hormone (TRH) is synthesized in the paraventric ular nucleus (PVN) of the hypotha la mus and stimulates synthesis and secretion of thyroid stimulating hormone (TSH) from 
thyrotroph cells in the anterior pituitary gland. TSH subsequently acts via the TSH receptor (TSHR) on thyroid follicular cells to stimulate synthesis and release of 3,5,3',5'-L-tetraiodothyronine (thyroxine, T4) and 3,5,3'-Ltriiodothyronine (T3). The circulating $\mathrm{T} 4$ and $\mathrm{T} 3$ are predominantly bound to camier proteins including thyroxine binding globulin, transthyretin (previously known as thyroxine binding pre-albumin) and albumin, with only approximately $0.2 \%$ of the total $\mathrm{T} 3$ and $0.02 \%$ of the total T4 available as free unbound homones (fT3, fT4) in plasma.

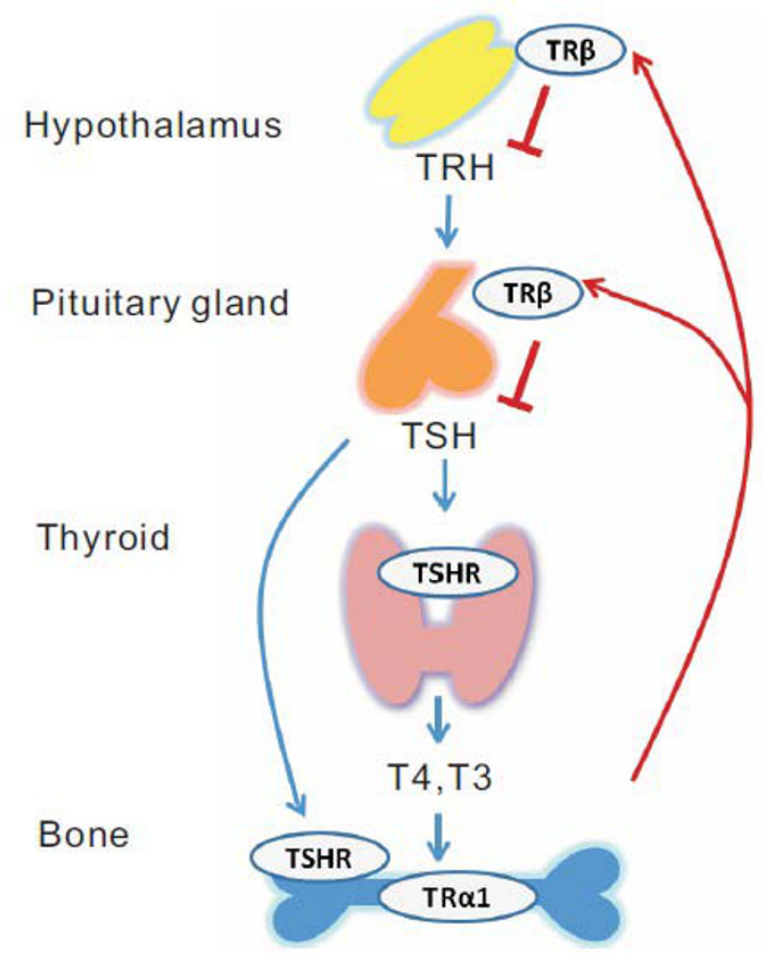

Figure 1 TRH-TSH-T3 feedback loop. The hypothalamic neurons secrete thyrotropin releasing hormone (TRH) which is carried down to the adenohypophysis of the pituitary by the hypothalamic portal vein where it releases thyroid stimulating hormone (TSH). The released TSH reaches thyroid glands via blood stream to bind to TSH receptor (TSHR) to stimulate production and release of thyroxin (T4) and T3. T3 exerts its actions on bone mainly by binding to TRa. TSH can also act directly on bone cells by binding to TSHR. Increased levels of T3 can act by negative feedback loop via TR $\beta$ to inhibit release of TRH and TSH, thereby preventing hyperparathyroidism.

$\mathrm{TH}$ is known to act via the nuclear $\mathrm{TH}$ receptor $\beta(\operatorname{TR} \beta)$ in the hypothalamus and pituitary to inhibit TRH and TSH production and secretion (4-5) and thus complete a negative feedback loop that maintains systemic thyroid status within a nomal reference range. This negative feedback loop maintains a physiological inverse relationship between TSH and circulating $\mathrm{T} 3$ and $\mathrm{T} 4$ levels that defines the HPTaxis set-point (6-7).

\section{Metabolism}

The predominant circulating $\mathrm{TH}$ is the pro-homone $\mathrm{T4}$, which can be converted to the biologically more potent homone, T3. TH metabolism is mediated by three iodothyronine deiodinases. The type 1 and type 2 enzymes (D1 and D2) convert T4 to T3 by catalyzing removal of a 5 '-iodine atom. By contrast, the type 3 enzyme (D3) irreversibly removes a 5-iodine atom from either $\mathrm{T} 4$ or $\mathrm{T3}$ to generate the inactive metabolites 3,3',5'-L-triiodothyronine (reverse $T 3, r T 3$ ) and 3,3'-diiodothyronine (T2), respectively (8-9). D1 is not expressed in skeletal cells (10-11), indicating D1 does not influence $\mathrm{T} 3$ action on bone directly. D2 is restricted to mature primary osteoblasts but is undetectable in chondrocytes and osteoclasts (12).

The cellular influx as well as efflux of iodothyronines is known to be mediated by several specific membrane transporter proteins including the monocarboxylate transporters 8 and 10 (MCT8 and MCT10), sodiumdependent organic anion co-transporting polypeptide 1 (OATP1), the sodium taurocholate co-transporting polypeptide (NTCP) and the L-type amino acid transporter 1 (LATI) and LAT2 (13-15). A study by Capelo et al revealed that $M C T 8, L A T 1$ and LAT2 are expressed in the skeletal tissues of mice as well as in osteoblastic MC 3T3E1 cells (16). Thus, the intra-cellular levels of the active homone, $\mathrm{T}$, and its a vailability to nuclear $\mathrm{TH}$ receptors (TRs) are determined by the relative activities of D2 and D3 as well as expression levels of $\mathrm{TH}$ transport proteins.

\section{$\mathrm{TH}$ receptor/ $\mathrm{TH}$ action}

The major action of $\mathrm{TH}$ is exerted through nuclear $\mathrm{TH}$ receptors (TRs), which are ligand-inducible transcription factors. Based on chromosomal localization and amino acid homology, two classes of TRs, a and $\beta$, have been identified. Due to differential splic ing of these two genes, multiple TRs are generated as $a 1, \alpha 2, a 3, \beta 1, \beta 2$, and $\beta 3$, as well as three truncated forms, $\Delta a 1, \Delta a 2, \Delta \beta$ (17-18). The $a 2$ and $a 3$ isoforms and all of the truncated receptors are non-T3 binding proteins that function as antagonists of $\mathrm{TH}$ signaling (18-20). TRal and $\operatorname{TR} \beta 1$ are expressed in virtually all tissues, but their abundance and roles differ, depending on the developmental stage of the organism and on the partic ular tissue type (21). TRa1 is more abundantly expressed in heart, brain, and bone, while TRB1 is more highly expressed in liver and pituitary (22). By contrast, expression of TRß2 is restricted to the hypothalamus and pituitary where it mediates inhibition of TRH and TSH expression and the cochlea and retina where it regulates sensory organ development (23-24) 
and TRB3 is expressed in kidney, liver, and lung (25). Thus, $\mathrm{TH}$ action in target tissues is determined in part by the typesand abundance of $\mathrm{TH}$ receptors present.

In the nucleus, TRs form homodimers with a nother TR or heterodimers with retinoid $X$ receptors (RXR) and bind to specific $\mathrm{TH}$ response element sequences (TRES) located in promoter regions of T3-target genesand regulate their expression in a ligand-dependent manner. Unliganded TRs bind TRES in T3 target genes and mediate transcriptional repression. Co-repressor proteins such as nuclear receptor corepressor protein/silencing mediator of retinoid and $\mathrm{TH}$ receptors are recruited to the $\mathrm{RXR}-\mathrm{TR}$ heterodimer in the absence of $\mathrm{T} 3$ and inhibit target gene expression. $\mathrm{T3}$ binding displaces the co-repressor, allowing co-ac tiva tor proteins such as CBP/p300, pCAF, and SRC-1 to interact with the RXR-TR heterodimer and activate gene transcription in a homone-dependent manner (26-28).

Besides the genomic actions of $\mathrm{T} 3$, nongenomic mechanism of $\mathrm{TH}$ ana logues a re increasingly recognized to have downstream consequences at the level of spec ific gene transcription $(26,29)$. The nongenomic mechanisms of $\mathrm{TH}$ are known to be initiated at the plasma membrane, in the cytoplasm or in the intracellular organelles, such as mitochondria. At the membrane level, $\mathrm{TH}$ may interact with integrin $\alpha \mathrm{V} / \beta 3$ to activate ERK1/2 which culminates in regulation of ion transport systems or cell proliferation (30). The relative contribution of nongenomic mechanisms in mediating $\mathrm{TH}$ effects on skeletal development is yet to be determined.

\section{Skeletal development}

The skeleton in different parts of the body develops through two distinct processes, intramembranous ossification and endochondral ossification. Intramembranous ossification, which occurs in the flat bones of the skull, involves direct differentiation of embryonic mesenchymal cells into bone-forming osteoblasts without an intermediate cartilage model (31). By contrast, endochondral ossification, which occurs in the remainder of the skeleton, involves the replacement of a cartilage model by bone tissue. Mesenchymal precursor cells condense and differentiate into chondrocytes, which secrete matrix proteins to form a cartilage template. The model expands through chondrocyte proliferation. Ossification of the cartilage model is preceded by hypertrophy of the chondrocytes in the prospective mid-shaft of the bone. Subsequently, blood vessels, osteoc lasts (cartilageand bone-resorbing cells), as well as bone marrow and osteoblast precursors then invade the model from the bone collar and proceed to form the primary ossifica- tion center. The primary center expands towards the ends of the cartilage model, as the osteoclasts remove cartilage extracelluar matrix (ECM) and osteoblasts deposit bone on cartilage remnants. In long bones, secondary ossification centers form within cartilage at the ends of long bones and remain separated from the primary ossification center by the epiphyseal growth plates. Skeletal maturity occurs when the expanding primary ossification center meets the secondary ossification center, thus obliterating the growth plate. The ordered process of growth plate chondrocyte proliferation, hypertrophic differentiation, apoptosis and subsequent new bone formation mediates linear growth until adulthood (32).

The process of endochondral ossification and the rate of linear growth are tightly regulated by multiple systemic homones (including THs, growth homone $(\mathrm{GH})$, gluc oc ortic oids and sex steroids) and various cytokines and growth factors (including insulin-like growth factor 1 (IGF-1), parathyroid hormone-related peptide (PTHrP), Indian hedgehog (Ihh), bone morphogenetic protein (BMP)s, fibroblast growth factor (FGF)s and vascular endothelial growth factor (VEGF)s that act in a paracrine and autocrine manner (33). The interaction between systemic hormones and local factors play a critical role in regulating linear growth, bone mass accumulation and mineralization processes until peak bone mass (34) is a chieved in early adulthood. Throughout adult life there is a gradual loss of bone mass, which in women is accelerated at the menopause. Excessive $\mathrm{TH}$ as in the case of hyperthyroidism in adults is known to induce increased bone tumover and fracture incidence (35-36). While $\mathrm{TH}$ is known to be involved in regulating development of peak bone mass during early childhood and in the maintenance of bone mass in adults, this review will focus on the mechanism of $\mathrm{TH}$ action in regulating skeletal development.

\section{Effects of TH on skeletal development}

A number of genetic mouse models (37-38) have been generated to date to elucidate the role of the $\mathrm{TH}$ axis on growth and development of a number of tissues including bone. The skeletal phenotypes of these mutant mouse models will be described below.

Skeletal phenotype of $\mathrm{TH}$ signaling related mutant mice (Table 1)

Mouse mutants with altered TSH or TH levels

Pax8-/- mice lack the thyroid specific transcription factor Pax8 required for thyroid follic ular cell formation (39-40) and hyt/hyt mice have a loss-of-function mutation in the 
Table 1 Skeletal phenotype of TH signaling related mutant mice

\begin{tabular}{|c|c|c|c|c|}
\hline $\mathrm{KO}$ & Deleted Protein & Skeletal Phenotype & TH-pituitary axis & Reference \\
\hline $\mathrm{Pax8}$ & $\begin{array}{l}\text { Lack of essential } \\
\text { transcription factor } \\
\text { Pax8 for thyroid } \\
\text { follicular cell } \\
\text { development }\end{array}$ & $\begin{array}{l}\text { Impaired linear growth, delayed } \\
\text { endochondral ossification; reduced } \\
\text { cortical bone ; reduced bone } \\
\text { mineralization }\end{array}$ & $\begin{array}{l}\text { No thyroid } \\
2000 \text { fold elevation of TSH and } \\
\text { undetectable TH } \\
\text { Functional TSHR }\end{array}$ & $\begin{array}{l}\text { mansouri et } \\
\text { al. (39); } \\
\text { Friedrichsen } \\
\text { et al. (40) }\end{array}$ \\
\hline TSHR & Tshr deleted & Die unless treated with $\mathrm{TH}$ after weaning & $\begin{array}{l}\text { Thyroid hypoplasia } \\
\text { Undetectable T4 and T3, } \\
\text { elevated TSH }\end{array}$ & $\begin{array}{l}\text { Marians et al. } \\
\text { (46) }\end{array}$ \\
\hline Hyt/hyt & $\begin{array}{l}\text { Loss of function } \\
\text { mutation in the Tshr } \\
\text { gene }\end{array}$ & $\begin{array}{l}\text { Impaired linear growth, delayed } \\
\text { endochondral ossific ation; reduced } \\
\text { cortical bone ; reduced bone } \\
\text { mineralization }\end{array}$ & $\begin{array}{l}2000 \text { fold elevation of TSH and } \\
\text { low } \mathrm{TH} \\
\text { Non-functional TSHR }\end{array}$ & $\begin{array}{l}\text { Bea mer et al. } \\
(42) ; \text { Gu et al. } \\
(43)\end{array}$ \\
\hline $\mathrm{D} 2$ & Deiodinase 2 & Nomal development and growth & Increase in $\mathrm{T} 4$ and $\mathrm{TSH}$, nomal T3 & $\begin{array}{l}\text { Bassett et } \\
\text { al.(48) }\end{array}$ \\
\hline TRa & $\begin{array}{l}\text { a } 1 \text { and } \mathrm{a} 2 \text { deleted } \\
\text { Increase } \Delta \text { a } 1 \text { but } \\
\text { nomal } \Delta \mathrm{a} 2 \text { and TR } \beta \\
\text { expression }\end{array}$ & $\begin{array}{l}\text { mice die within } 5 \text { weeks } \\
\text { Severe growth retardation; delayed } \\
\text { endochondral ossification; impaired } \\
\text { chondrocyte differentiation; reduced } \\
\text { mineralization }\end{array}$ & $\begin{array}{l}\text { Severe hypothyroidism (T3 } \\
\text { and T4 are } 10 \% \text { of WT levels); T3 } \\
\text { injections rescue phenotype ; GH } \\
\text { nomal }\end{array}$ & $\begin{array}{l}\text { Fraichard et } \\
\text { al. (17) }\end{array}$ \\
\hline TRal & $\begin{array}{l}\text { a } 1, \Delta a 1 \text { deleted } \\
\text { Normal } a 2, \beta 1 \text { and } \beta 2 \\
\text { expression }\end{array}$ & $\begin{array}{l}\text { No growth retardation } \\
\text { Not detemined }\end{array}$ & $\begin{array}{l}\text { Mild hypothyroidism in males but } \\
\text { not females }\end{array}$ & $\begin{array}{l}\text { Wikstrom et } \\
\text { al. (122) }\end{array}$ \\
\hline TRa2 & $\begin{array}{l}\text { a } 2, \Delta a 2 \text { deleted } \\
\text { Increase in a } 1 \\
\text { expression }\end{array}$ & $\begin{array}{l}\text { No difference in the length of femur and } \\
\text { tibia } \\
\text { Nomal endochondral ossific ation }\end{array}$ & $\begin{array}{l}\text { Mild hypothyroidism } \\
\text { Nomal GH and low IGF-1 }\end{array}$ & $\begin{array}{l}\text { Salto et al. } \\
\text { (123) }\end{array}$ \\
\hline $\mathrm{TRa}^{\mathrm{o} / 0}$ & $\begin{array}{l}\text { a } 1, \Delta a 1, a 2, \Delta a 2 \\
\text { deleted }\end{array}$ & $\begin{array}{l}\text { Transient growth retardation; delayed } \\
\text { endochondral ossification; impaired } \\
\text { chondrocyte differentiation; reduced } \\
\text { minera lization }\end{array}$ & $\begin{array}{l}\text { Slight decrease in T4, nomal TSH } \\
\text { and T3; Nomal GH and IGF-1 }\end{array}$ & $\begin{array}{l}\text { Gauthieret al. } \\
(52)\end{array}$ \\
\hline $\mathrm{TRa}]^{\mathrm{PV} /+}$ & $\begin{array}{l}\text { Heterozygous dominant } \\
\text { negative TRa receptor }\end{array}$ & $\begin{array}{l}\text { Severe persistent growth reta rdation; } \\
\text { delayed intramemebra nous and } \\
\text { endochondral ossific ation; impaired } \\
\text { chondrocyte differentiation; reduced } \\
\text { mineralization }\end{array}$ & $\begin{array}{l}\text { Mild and transient systemic } \\
\text { hypothyroidism } \\
\text { Nomal GH, reduced IG F-1 }\end{array}$ & $\begin{array}{l}\text { Kaneshige et } \\
\text { al. (53) }\end{array}$ \\
\hline $\operatorname{TR} \beta$ & TR $\beta 1, \beta 2$ deleted & $\begin{array}{l}\text { Nomal growth } \\
\text { Persistent short stature; advanced } \\
\text { endochondral and intra membraneous } \\
\text { ossification; increased mineralization }\end{array}$ & $\begin{array}{l}\text { RTH and goiter; Increase in } \mathrm{T} 4, \mathrm{~T} 3 \\
\text { and TSH }\end{array}$ & $\begin{array}{l}\text { Forrest et al. } \\
\text { (5) }\end{array}$ \\
\hline TRß2 & $\begin{array}{l}\text { TR } 32 \text { deleted } \\
\text { Normal TR } 1 \text { 1, TR a } \\
\text { expression }\end{array}$ & Nomal growth Not determined & $\begin{array}{l}\text { Mild RTH ; Increase in T4,T3 and } \\
\text { TSH; 30\% decrease in GH }\end{array}$ & $\begin{array}{l}\text { Abel et al. } \\
(23)\end{array}$ \\
\hline TR $\beta$ PV/PV & $\begin{array}{l}\text { Homozygous dominant } \\
\text { negative TR } \beta \text { receptor }\end{array}$ & $\begin{array}{l}\text { Accelerated prenatal growth; persistent } \\
\text { postnatal growth retardation; advanced } \\
\text { intramembraneous and endochondral } \\
\text { ossification; increased mineralization }\end{array}$ & $\begin{array}{l}\text { Severe RTH and goiter ; } 400 \text { fold } \\
\text { elevation of TSH, and } 15 \text { fold } \\
\text { elevation of T4 ; Reduced GH } \\
\text { and increased IGF-1 }\end{array}$ & $\begin{array}{l}\text { Kaneshi et al. } \\
\text { (59); O'shea } \\
\text { et al. (57-58); } \\
\text { Bassett et al. } \\
\text { (56) }\end{array}$ \\
\hline TRa;TR $\beta$ & $\begin{array}{l}\text { a } 1, a 2, \beta 1 \text { and } \beta 2 \\
\text { deleted }\end{array}$ & $\begin{array}{l}\text { mice die within } 5 \text { weeks } \\
\text { Disorganization of growth plate; delayed } \\
\text { endochondral ossific ation; impaired } \\
\text { chondrocyte differentiation; reduced } \\
\text { mineralization }\end{array}$ & $\begin{array}{l}\mathrm{RTH} \text { and small goiter ; Increase in } \\
\mathrm{T} 3, \mathrm{~T} 4 \text { and } \mathrm{TSH} ;\end{array}$ & $\begin{array}{l}\text { Gauthieret al. } \\
\text { (111) }\end{array}$ \\
\hline
\end{tabular}


Cons.

\begin{tabular}{|c|c|c|c|c|}
\hline $\mathrm{KO}$ & Deleted Protein & Skeletal Phenotype & TH-pituitary axis & Reference \\
\hline TRal;TR $\beta$ & $\begin{array}{l}\text { a } 1, \Delta \text { al, } \beta 1 \text { and } \beta 2 \\
\text { deleted }\end{array}$ & $\begin{array}{l}\text { Persistent growth reta rdation; delayed } \\
\text { endochondral ossific ation; reduced } \\
\text { minera lization }\end{array}$ & $\begin{array}{l}\text { RTH and large goiter; Several fold } \\
\text { increase in total and free } \mathrm{T} 3, \mathrm{~T} 4 \\
\text { increase in TSH; reduced } \\
\text { GH/IGF-1 }\end{array}$ & $\begin{array}{l}\text { Gothe et al } \\
\text { (124) }\end{array}$ \\
\hline TRa2;TR $\beta$ & $\begin{array}{l}\mathrm{a} 2, \Delta \mathrm{a} 2, \beta 1 \text { and } \beta 2 \\
\text { deleted }\end{array}$ & Transient growth delay & Mild hypothyroidism & $\begin{array}{l}\text { Ng et al. } \\
\text { (125) }\end{array}$ \\
\hline TRa $/ 0 ; \operatorname{TR} \beta$ & $\begin{array}{l}a 1, \Delta a 1, a 2, \Delta a 2, \beta 1 \\
\text { and } \beta 2 \text { deleted }\end{array}$ & $\begin{array}{l}\text { Disorganization of growth plate; growth } \\
\text { delay; delayed endochondral ossification; } \\
\text { impaired chondrocyte differentiation; } \\
\text { reduced mineralization }\end{array}$ & $\begin{array}{l}\mathrm{RTH} \text { and goiter; More than 10-fold } \\
\text { increase in T4,T3 and TSH ;marked } \\
\text { reduction in GH/IGF-1 }\end{array}$ & $\begin{array}{l}\text { Gauthier et } \\
\text { al. (52) }\end{array}$ \\
\hline
\end{tabular}

TSH receptor (TSHRP556L) (41-43). Both mutants have a 2000-fold elevation of TSH and undetectable THs, but the TSHR is functional in Pax8 ${ }^{-1-}$ mice whereas it is nonfunctional in hyt/hyt mice. Thus, the reciprocal relationship between $\mathrm{TH}$ s and $\mathrm{TSH}$ rema ins intact in $\mathrm{Pax} 8^{-1-}$ mice but is disnupted in hyt/hyt mice (44). Both mutants exhibited a similar skeletal phenotype of impaired linear growth, delayed endochondral ossification, impaired chondrocyte differentiation, reduced cortical bone, impaired trabecular bone remodeling and reduced bone mineralization (44-45). These data indicate that any action of TSH in bone is likely to be minor when compared to the effects of $\mathrm{T3}$.

TSHR knockout mice (TSHR ${ }^{-1}$ ) present with developmental and growth delaysand severe osteoporosisat all sites and profound hypothyroidism, with no detectable T4 and T3 and elevated TSH. The TSHR knockout mice die within 1 week of weaning unless treated with $\mathrm{TH}$ supplementation (46). $\mathrm{TH}$ replacement after weaning did not nomalize the low bone mineral density in $\mathrm{TSHR}^{-1-}$ mice and these mice showed a dramatic increase in bone tumover. These findings confirmed that the bone loss was independent of $\mathrm{T} 3$ and $\mathrm{T} 4$ levels. Thus, an independent role for TSH in negative regulation of bone remodeling wasproposed (47) .

Deiodinase D2 knockout mice were generated to investigate the effects of osteoblast-specific T3 deficiency (48) because D2 expression was detected only in mature osteoblasts (12). The D2 knockout mice exhibit pituitary resistance to feedback regulation by $\mathrm{T} 4$ characterized by an increase in TSH and T4, but nomal T3. Overall growth as well as skeletal development was found to be nomal in D2 knockout mice indicating an insignificant role for D2 during endochondral and intramembranous ossification in vivo. However, adult D2 knockout mice had brittle bones due to increased mineralization and reduced bone formation because of restricted cellular hypothyroidism in osteoblasts (48). Furtherstudiesare needed to determine the mechanism for reduced bone formation in the D2 conditional knockout mice.

Dual oxidase generates the hydrogen peroxide required by thyroid peroxidase for the incorporation of iodine into thyroglobulin. Dual oxidase 2 (Duox2) mutant mice, genetic model for congenital hypothyroidism, exhibit low T4 and high TSH caused by lack of T4 feedback to the pituitary gland and is associated with dwarfing and hearing impaiment. Concomitant with small size and low aBMD, circulating levels of IGF-1 are lower in the mutants. These phenotypes of Duox2 mutant mice are consistent with lack of $\mathrm{TH}$ support, a key role for $\mathrm{TH}$ in skeletal development (49). Further studies are needed to investigate the specific functions of Duox2 in other tissues.

\section{TRa mutants}

Several TRa knockout mice have been generated and this has led to the identification of additional TRa isoforms expressed from a promoter within intron 7 of the THRA gene (50). As a result only TRa ${ }^{0 / 0}$ mice lack all TRa isoforms whereas other TRa mutants retain truncated isoforms with dominant-negative activity. $\mathrm{TRa}^{0 / 0}$ mice lack all $\mathrm{TRa}$ isoforms and are systemically euthyroid. During development $\mathrm{TRa}^{0 / 0}$ mice display features of skeletal hypothyroid ism with transient growth retardation and with delayed endochondral ossification characterized by impaired chondrocyte differentiation and reduced mineralization (51-52).

Mice harboring dominant-negative mutations of TRal in different genetic backgrounds have mild and transient systemic hypothyroidism but they also exhibit a more severe phenotype of delayed skeletal development than $\mathrm{TRa}^{0 / 0}$ mice. $\mathrm{TRa}^{\mathrm{PV} /+}$ mice are most severely affected, displaying persistent post-natal growth retardation and markedly delayed endochondral ossification and decreased mineralization $(38,53)$.

Deletion or mutation of TRa does not affect systemic thyroid status but caused local skeletal hypothyroidism 
while the presence of a dominant-negative TRa leads to a more severe skeletal phenotype than receptor deficiency alone. These findings demonstrate an important role for unliganded TRal acting as a potent dominantnegative antagonist (54). The repressive actions of the unliganded receptor, therefore, have a greater physiologic effect than having no receptor at all. Consistent with this phenotype, skeletal expression of the $\mathrm{T} 3$ target genes, fibroblast growth factor receptors (FG FR) 1 and 3, were reduced $(51,55-56)$.

\section{$\mathrm{TR} \beta$ mutants}

Deletion of TR $\beta$ results in elevated T4, T3 and TSH levels consistent with resistance to $\mathrm{TH}(\mathrm{RTH})$. In contrast to TRa mutants, during development $\mathbb{T R} \beta^{-/-}$mice display features of skeletal hyperthyroidism with advanced endochondral and intramembranous ossification, accelerated chondrocyte differentiation, increased mineralization and persistent short stature due to premature growth plate quiescence $(5,23,51)$.

Mice harboring a dominant-negative mutation in THRB (TR $\beta^{P V / P V}$ ) have severe $\mathrm{RTH}$ and exhibit a more severe phenotype than $\operatorname{TR} \beta^{-1-}$ with accelerated prenatal growth characterized by advanced endochondral and intramembraneous ossification (57-59). Consistent with phenotype, increased skeletal expression of the T3 target genes, FGFR1 and 3, (51, 55-56) revealed the presence of enhanced $\mathrm{T} 3$ action resulting from supraphysiological stimulation of TRa in bone. Thus, deletion or mutation of TR $\beta$ disrupts the HPT axis resulting in skeletal thyrotoxicosis. The presence of a dominant negative TR $\beta$ leads to a more severe skeletal phenotype than receptor deficiency alone. In summary, during development reduced $\mathrm{T} 3$ action in TRa mutant mice results in delayed ossification and reduced mineralization whereas increased $T 3$ action in TR $\beta$ mutant mice leads to advanced ossification and increased mineralization.

Clinical manifestation of $\mathrm{TH}$ signaling related mutations in humans (Table 2)

The developing skeleton is sensitive to thyroid status and childhood hypothyroidism is characterized by growth retardation, delayed bone age and short stature, whereas juvenile thyrotoxic osis accelerates growth and advances bone age but results in persistent short stature due to premature fusion of the epiphyses $(2,60-61)$. A loss of function mutation of the TSH $\beta$-subunit results in TSH defic iency and congenital hypothyroidism. Two affected siblings received $\mathrm{TH}$ replacement from birth but despite the lifelong absence of TSH, their skeletal development and bone mineral density were nomal (62). These findings suggest that TSH is not required for nomal skeletal development and growth. TSHR mutations result in wide spectrum of clinical manifestations ranging from mild to severe hypothyroidism and hyperthyroidism (63). Up to this da te more than 40 kinds of loss of function mutations in the TSHR gene have been reported as the causative defect in congenital hypothyroidism (64). By contrast, gain of function mutations in the TSHR gene were identified in familial non-autoimmune hyperthyroidism or spora dic non-autoimmune hyperthyroidism (65).

The syndrome of resistance to $\mathrm{TH}(\mathrm{RTH})$ is caused by decreased tissue responsiveness to $\mathrm{TH}$ and was first described in 1967 (66-67). Clinic al features include goiter, elevated circulating $\mathrm{TH}$ levels, nonsuppressed serum TSH level, clinical euthyroidism, and tachycardia; some individuals also demonstrate attention deficit disorder and deficits of linear growth, hearing, and bone formation (66). The RTH genetic defect is caused mostly by mutations of $\mathrm{TH}$ receptor $\beta$ gene. A dominantnegative mutation of TR $\beta$ blunts negative feedback in the HPTaxis and is characterized by elevated T4 and T3 and an inappropriately normal or elevated TSH. RTH patients display variable skeletal phenotypes that are difficult to interpret due to confounding effects of treatment and the heterogeneity of TR $\beta$ mutations (66, 68). Nevertheless, reported features of increased bone tumover, osteoporosis, fracture and craniosynostosis in RTH suggest a predominant role for T3 in bone development (68). Last year, two families with a heterozygous mutation of THRA, resulting in expression of a dominant negative TRa protein, have been the first to be reported (69-70). Levels of free T4 and rT3 in these patients were in the low-nomal range and $\mathrm{T3}$ in the high-nomal range, with nomal TSH. Despite near nomal TH levels, patients displayed a phenotype consistent with the characteristic features of hypothyroidism that included short stature, delayed bone development, skeletal dysplasia and chronic constipation, thus suggesting that TRal plays a major role in human skeletal development. Recently, several patients with homozygous TR $\beta$ mutations were reported (71). The clinical manifestations are a combination of those found in individuals heterozygous for a mutation only in TRa or in TR $\beta$. Patients have a more severe RTH phenotype, goiter, hearing loss, and much greater elevations of senum $\mathrm{T3}, \mathrm{T3}$, and $\mathrm{TSH}$, than heterozygous individuals and also have neurological impairment and growth retardation, more characteristic of a deficiency in the action of TRa (69-70). These clinical phenotypes suggest the possible interference of the mutant TR $\beta$ with function of TRal.

A sex-linked form of mental retardation with motor abnoma lities, named the Allan-Herdon Dudley syndrome, was described in 1944 . When MCT8, a specific trans- 
Table 2 Clinical manifestation of TH signaling related mutations in humans

\begin{tabular}{llll}
\hline Clinical status & Mechanism & Clinical manifestation & TH-pituitary axis \\
\hline Congenital & Loss of function TSHR & Prolonged janudice, constipation, & Mild to severe \\
hypothyroidism & mutation & poorfeeding, umbilical hemia, & hypothyroidism or \\
& & macroglossia, wide open posterior & thyroid hypoplasia \\
& & fontanel and edematous and dry & (64)
\end{tabular}

\section{skin}

Resistance to Heterozygous dominant Short stature; delayed bone

Thyroid Homone negative TRa receptor

development; transient delay in motor development; mild impa iment of cognitive development; chronic constipation

Resistance to Homozygous dominant negative TRß receptor

Large goiter, dysmorphic features

severe tachycardia; developmental nonsupressed TSH and growth delay; mental

retardation; hearing deficit

Heterozygous dominant Variable, can induce goiter, hearing High T4 and T3; negative TRß receptor deficit; hyperactive behavior, leaming disability; developmental delay; tarchycardia

TH cell transporter MCT8 mutation defect(THCTD) Hypotonia, motor delay, feeding problem, no speech development, spasticity, cognitive impaiment, nomal lineargrowth

TH metabolism SECISBP2 mutation defect(THMD) nonsuppressed TSH

Refetoff et al. (66-67);

Low nomal free $\mathrm{T} 4$ and Boucukova et al. rT3; High T3; Nomal TSH (69); van Mullem et al. (70)

Ferrara et al. (71) Weiss et al. (126)

High serum $\mathrm{T} 3$ and low rT3and T4; Nomal or

Friesema et al. (72); Dumitrescu et al. (73) slightly elevated TSH

High T4 and rT3; Low T3; Dumitrescu et al. (74); Slightly elevated TSH. Refetoff et al. (66) porter of $\mathrm{TH}$, was sequenced in these patients, inactivating mutations were identified in some individuals (72-73). Patients manifest with truncal hypotonia, poor head control, and later spasticity and were found to have abnomal thyroid function (elevated serum $\mathrm{T} 4$ and rT3 and low T3).

Deiodina ses are selenoprote ins that catalyze iodothyronine deiodination and are important in $\mathrm{TH}$ activation and inactivation. Selenium is an essential trace element required for the biosynthesis of selenoproteins and selenocysteine insertion sequence binding protein 2 (SECISBP2), a key trans-acting factor. Patients with mutations in the SECISBP2 gene presented with transient growth retardation associated with abnomal thyroid function, low T3, high T4 and rT3, and slightly elevated TSH (74). Thus, there are a number of clinical genetic studies with mutations in genes related to the $\mathrm{TH}$ signaling pathway that attest the importance of $\mathrm{TH}$ in the regulation of skeletal metabolism.

Effects of T3 in bone cells in vitro

Chondrocytes

TRa1 and TR $\beta 1$ are expressed in resting and proliferating chondrocytes in the growth plate, suggesting these cells are direct targets for $\mathrm{T3}$ actions (75). T3 stimula tes c lonal expansion of resting chondrocyte progenitor cells but inhibits subsequent chondrocyte proliferation, while stimulating hypertrophic differentiation (75-79). Accordingly, T3 induces markers of hypertrophic chondrocyte differentiation, including alkaline phosphatase and collagen $X$ expression in primary growth-plate chondrocyte cultures, and enhances cartilage matrix mineralization (75). T3 also stimulates the expression of proteoglycan and collagen-degrading enzymes including aggrecanase-2 (a disintegrin and metalloproteinase with thrombospondin motifs1, ADAMTS5) and matrix meta lloproteinase 13 (MMP13) (78, 80-81). T3 regulation of growth plate chondrocyte proliferation and differentiation in vitro has been shown to involve a number of growth factor signaling pathways including IGF-1, Wnt, the Ihh/PTHrP feedback loop and FGFR3 (Figure 2) (55, 82-83). In conclusion, TH stimulates maturation of chondrocytes and the progression of endochondral ossification and is essential for linear growth.

\section{Osteoblasts}

T3 has been found to stimulate, inhibit, or exert no effect on osteoblastic cell proliferation, but a consensus 


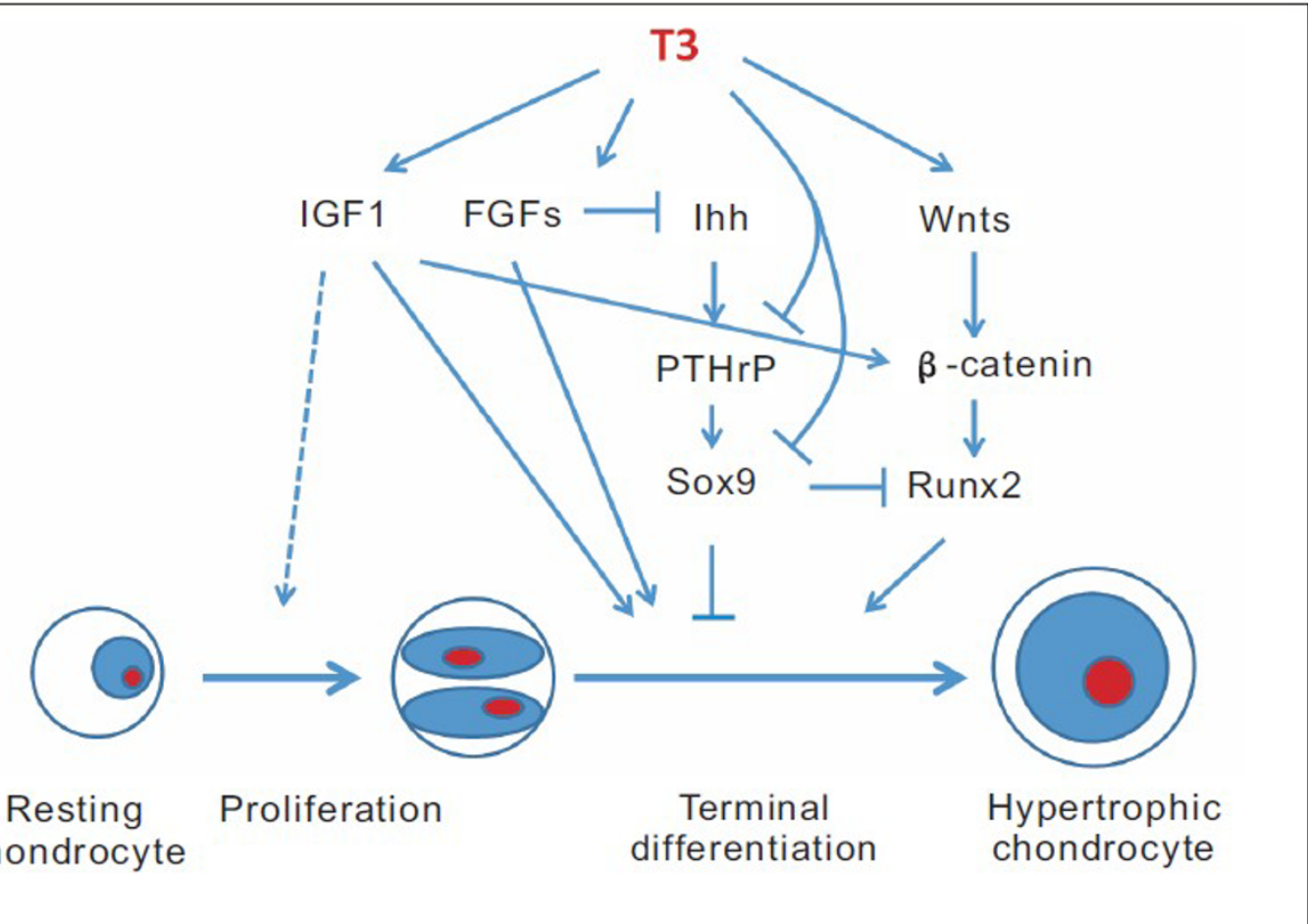

Figure 2 Mechanisms for T3 regulation of chondrocyte differentiation. T3 can modulate local actions of growth factors such as IGF-I, FGFs, Wnts, Ihh and PTHrp to regulate proliferation and differentiation of cells of chondrocytic lineage. The differentiating promoting actions of T3 on chondrocytes are known to be mediated via inhibition of Sox9 and stimulation of Runx2 expression.

suggests that T3 stimulates osteoblast activity (1). T3 has been shown to increase expression of the osteoblast differentiation markers collagen I, osteocalc in, osteopontin, alkaline phosphatase, MMP9 and MMP13 in osteoblasts (81, 84-87). In addition, T3 modulates key pathways involved in osteoblast proliferation and differentiation. T3 stimula tes osteoblast responses to IG F1, PTH and FGFs both in cell cultures and in vivo (88-90). These observations demonstrate that $\mathrm{T}$ stimulates osteoblast activity by complex direct and indirect mecha nisms involving many growth factors and cytokines (Figure 3).

Moreover, the nuclear factors constituting the $\mathrm{TH}$ receptor coactivator complex and the molecular pathways by which $\mathrm{TH}$ mediates its effects on target gene expression in osteoblasts remain poorly understood. Recently, we have shown that diabetes- and obesityrelated protein (DOR), a key modulator of $\mathrm{TH}$ function in musc le cells, is differentially regulated by $\mathrm{TH}$ and acts as a stimulatory mediator of $\mathrm{TH}$ effects in osteoblasts (91).

\section{Osteoclasts}

$\mathrm{TH}$ direc tly stimula tes bone resorption in organ cultures of mouse calvaria (92) and fetal rat limb bones (93-94). Earlier reports showed that T3 stimulated osteoclastic bone resorption in the presence of osteoblasts, but not in their absence (95-96). These findings imply that $\mathrm{TH}$ indirectly stimulates osteoc lasts via inc reased expression of RANKL and other cytokines involved in osteoclastogenesis including interleukin 6 (IL-6), IL-8 and prostaglandin E2 (PGE2) in osteoblasts $(92,97-98)$. Several studies have demonstrated apparent expression of $\mathbb{T R}$ proteins in all bone cell lineages, however, it is not clear whether osteoclasts express TRal and TRß1 mRNAs because currently available $\mathrm{TR}$ antibodies are of low affinity, thus compromising the detection of endogenous TRs $(75,99)$. Thus, it remains unclear whether the effects of $\mathrm{T} 3$ to promote bone resorption result from direct actions in osteoclasts or indirect effects mediated by osteoblasts.

\section{Mechanism of TH action in the developing skeleton}

Interaction with the Growth homone /IGF-1 signaling pathway

The importance of IGF-1 in skeletal development is well established because peak bone mass is considerably reduced as a consequence of deficiency of IGF-1 action in both humans and experimental animals (100102). IGF-1 is the major deteminant of post-natal growth, 


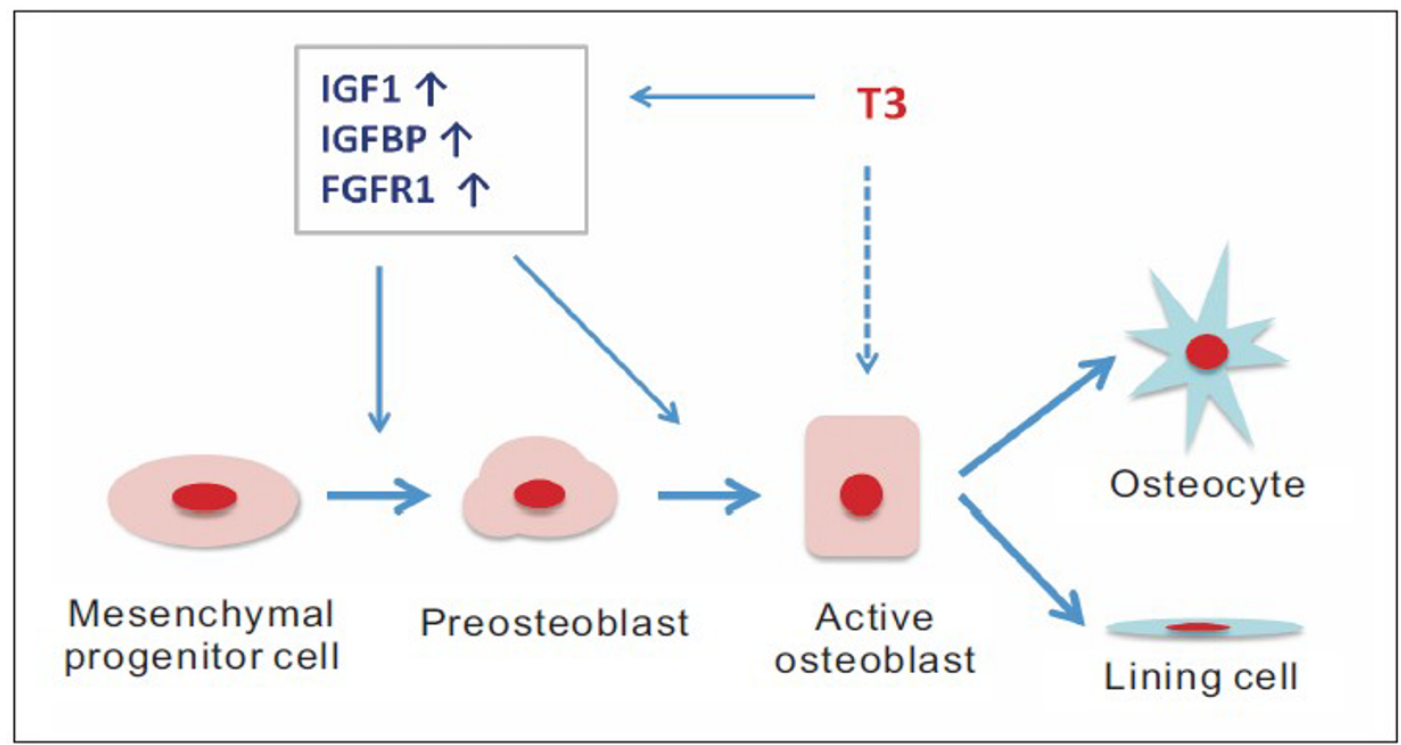

Figure 3 Mechanisms for T3 regulation of osteoblast differentiation. T3 increases local IGF-I actions by modulating production of IGF-I and/or its binding proteins and thereby stimulate differentiation of mesenchymal cells into osteoblast lineage. T3 can also stimulate local FGF actions by increasing FGF receptor expression in osteoblasts. T3 can also exert direct effects via TRE to regulate transcription of bone formation genes.

it mediates both GH-dependent and -independent effects and is involved in chondrocyte recruitment, proliferation and hypertrophic differentiation (103).

IGF-1 signaling is also required to maintain the IhhPTHrP loop during skeletogenesis. In fetal IGF1 ${ }^{-1-}$ mice, expression of thh was reduced in long bones, whereas expression of PTHrP was increased (104). Furthermore, Wang et al (105) have demonstrated that IGF-1/IGF1R induces Wnt4 expression and $\beta$-catenin activation. IGF-1/IGFIR actions on growth plate chondrocytes are neutralized by the Wnt antagonists SFRP3 and Dkk1, confiming that the Wnt/ $\beta$-catenin signaling pathway is downstrea m of IG F-1 signaling (Figure 2).

It is now known that IGF-1 expression in bone is regulated by $\mathrm{GH}$ as well as many systemic and local regulators of bone growth. In this regard, our previous studies showed that days 7 to 14 of the prepubertal period and days 23 to 31 of the pubertal period represent critical time points for skeletal growth as well as increases in serum IG F-I levels in mice (106). It was also determined that there is an important critical period during prepubertal growth when the effects of $\mathrm{GH}$ are small and IGF-I remains an important regulator (101). Recently, we demonstrated that $\mathrm{TH}$ is a major regulator of IGF-I expression, independent of $\mathrm{GH}$, during the prepubertal growth period (45). When we measured the postnatal changes in serum levels of total T3 and IGF-1 in C 57BL/6J mice, as seen in Figure 4, senum levels of IGF-1 increased almost three fold in mice duning the prepuberal growth period. This increase in IGF-1 was preceded by changes in serum T3 levels, which increased two-fold between day 7 and 14. Studies using genetic mouse modelsdeficient in $\mathrm{TH}$ found that senum levels of IGF-1 were reduced by more than $50 \%$ at day 21 compared to wild-type mice as a consequence of a decrease in IGF-1 expression in liver and bone. Daily administration of T3/T4 during the prepubertal growth period (days 5 to 14) increased IGF-1 expression in both liver and bone and nomalized the serum IGF-1 levels. Furthermore, in vitro studies in osteoblasts revealed that $\mathrm{TH}$, in the presence of TRal, bound to a TH response element in intron 1 of the IGF-1 gene to stimulate transcription (45). Thus, $\mathrm{TH}$ is a key regulator of both local and endocrine IGF-1 action during the prepubertal growth period.

In tems of the target cell types for $\mathrm{TH}$ effects on IGF-1 expression, we and others have found that $\mathrm{TH}$ treatment increased IGF-1 expression in bone cells and chondrocytes $(45,58,107)$. There is a lso evidence that $\mathrm{TH}$ is able to act directly on growth plate chondrocytes through $\mathrm{GH}$-independent mechanisms (108). Lewinson et al demonstrated that $\mathrm{TH}$ is able to stimulate longitudinal bone growth in animals in which $\mathrm{GH}$ secretion has been ablated by hypophysectomy (109). $\mathrm{TH}$ also stimulated chondrocyte differentiation in both thyroidectomized and hypophysectomized rats, a role for which growth homone cannot substitute (110). Thus, there is ample evidence that $\mathrm{TH}$ is essential for skeletal growth during the prepubertal growth period.

The relationship between $\mathrm{TH}$ signaling and GH/IGF-1 signaling is potentially complex due to multiple possible 
points of interaction at both the systemic and local levels. Through studies using a variety of transgenic mice in which $\mathbb{R}$ function has been altered, our understanding of this complexity has been improved. TRa $/ 0$ and TRalPV/+ mice showed nomal pituitary GH production, but diminished expression of GH receptor, IGF-1, and IGF-1 receptor in growth plate chondrocytes (52, 58). By contrast, pituitary GH production was reduced and $\mathrm{GH}$ receptor and IGF-1 expression in the growth plate was increased in TR $\beta^{-1-}$ and TR $\beta^{P V / P V}$ mice $(5,58$, 111). The different phenotypes between the $\mathrm{TRa}^{\mathrm{pv} /+}$ mice and $T R \beta^{P V / P V}$ mice can be explained by the known finding that the pituitary gland is a TRß-responsive tissue, while the growth plate is primarily a TRa-responsive tissue. Thus, GH/IGF1 signaling is also a local downstream mediator of $\mathrm{T} 3$ action in the growth plate.

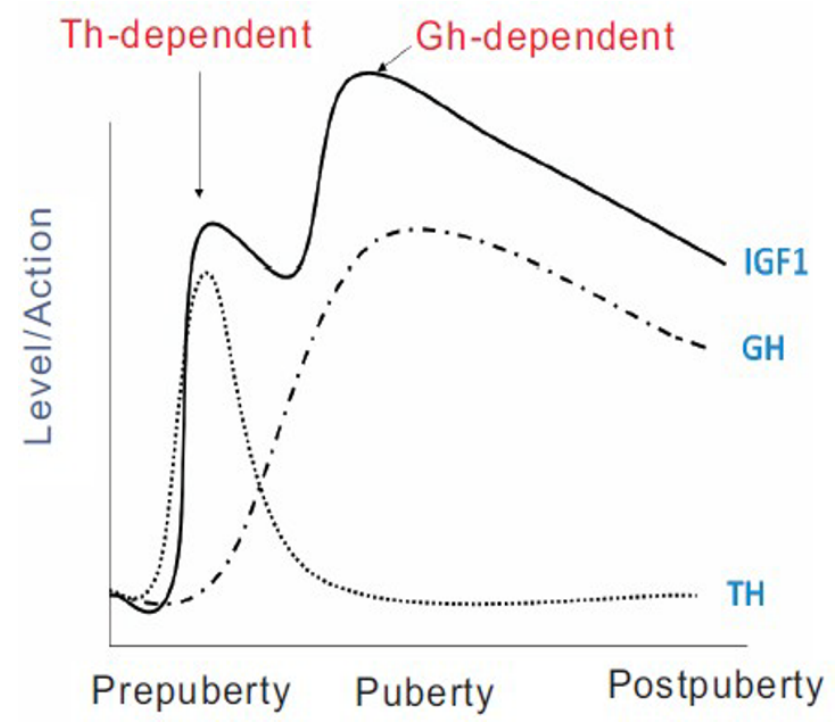

Figure 4 Model of $\mathrm{TH}$ regulation of skeletal growth in mice. It is proposed that the increase in IGF-I expression and bone accretion during prepubertal and pubertal growth periods are mediated via $\mathrm{TH}$ and GH-dependent mechanisms, respectively. Some of the effects of $\mathrm{TH}$ on bone growth are direct and occur independent of $\mathrm{GH}$.

GH therapy nomalized the decreased serum IGF-1 level of hypothyroid pups. However, growth failure, despite nomal serum IGF-1 concentrations in GH-treated hypothyroid rats, has been described earlier (112). Consistent with this, we found that inhibition of IGF-1 action only partially reduced $\mathrm{TH}$ effects on osteoblast differentiation and the rate of metatarsal bone mineralization (45). These results provide indirect evidence that $\mathrm{TH}$ acts via other pathways, in addition to IGF-1. It is known that $\mathrm{TH}$ influences fibroblast growth factor (FGF) receptor signaling in bone and interacts with the Wnt/ $\beta$-catenin and Ihh/PTHrP signaling pathways to regulate endo- chondral ossification (52-54). The extent to which IGF-1 interaction with other growth factor signaling pathways is involved in $\mathrm{TH}$ regulation of skeletal metabolism remains to be determined.

Interaction with the Ihh/PTHrP feedback loop

The pace of chondrocyte differentiation is precisely regulated by the Ihh/PTHrP paracrine negative feedback loop. Prehypertrophic chondrocytes secrete Ihh which diffuses to periartic ular cells to induce synthesis of PTHrP. PTHrP, acting via its receptor PTHR1, then completes the loop by stimulating chondrocyte proliferation and inhibiting further hypertrophic differentiation (113114). The effect of $\mathrm{TH}$ on the Ihh/PTHrP feedback loop has been studied in thyroid manipulated rats (83). In hypothyroid rats, growth plates were grossly disorganized and the expression of PTHrP was increased and extended throughout the growth plate, while the PTHrP receptor was expressed in the same location as in euthyroid animals. These changes in PTHrP receptor expression can lead to inhibition of hypertrophic chondrocyte differentiation and result in arrest of linear growth (Figure 2). In thyrotoxic growth plates, histology essentially wasnomal but PTHrP receptor (PTHrP-R) mRNA was undetectable, while PTHrP mRNA expression was unchanged. An absence of the PTHrP receptor results in negative PTHrP signaling and progression of hypertrophic chondrocyte differentiation to accelerate linear growth. Furthermore, recent studies in chicken tibia explants have shown that Ihh stimulates degradation of the type 2 deiodinase enzyme resulting in an induction of PTHrP expression (114). Together, these findings suggest that $\mathrm{TH}$ regulates the set point of the Ihh/PTHrP feedback loop to modulate the pace of chondrocyte differentiation and endochondral bone formation during postnatal growth.

Interaction with Fibroblast Growth Factor signaling Signaling through the FGF pathway has been demons trated to negatively regulate proliferation of growth plate chondrocytes. During endochondral ossification, FGFR2 is expressed in condensing mesenchyme and perichondrium, FGFR1 is present in prehypertrophic and hypertrophic chondrocytes, and proliferating chondrocytes express FGFR3. During linear growth, FGFR2 is not expressed in the growth plate, but FGFRI expression persists in prehypertrophic and hypertrophic cells, and proliferating chondrocytes express FGFR3 $(33,115)$. The role of FGFR1 and FGFR2 in the developing growth plate is poorly understood. However, FG FR3 has been predic ted to play an important role. Activating mutations in FGFR3 results in achondroplasia, the most common form of dwarfism in humans (115-116), whereas Fgfr3 knockout 
mice display limb overgrowth (117-118), indicating that FGFR3 is a negative regulator of linear growth. T3 stimulates expression of FG FR-1 and FGFR-2 mRNA in the ATDC5 chondrocytic cell line undergoing chondrogenesis, but stimulation of FG FR3 by T3 was greater and persisted longer, coinciding with the period in which $\mathrm{T3}$ inhibited chondrocyte proliferation and stimulated hypertrophic differentiation (55). Investigation of the FGF/FGFR signaling pathway in TR mutant mice revealed that FGFR 3 was reduced in growth plates of $\mathrm{TRa}^{0 / 0}$ and $\mathrm{TRa} \mathrm{I}^{\mathrm{PV} /+}$ mice and increased in TR $\beta^{-1}$ and TR $\beta^{\mathrm{PV} / \mathrm{PV}}$ mice (55-58). Taken together, these findings suggest that FGFR3 may play a role in mediating effects of $\mathrm{T3}$ on chondrogenesis. Some of the growth inhibitory actions of FGFR3 are mediated via reduced activity of the Ihh/PTHrP feedback loop (119). The interactions between FGFR3 and other growth factor signaling pathways in regulating chondrocytes still need to be worked out.

\section{Interaction with $W n t / \beta$-c atenin signa ling}

$W n t / \beta-C$ atenin signaling also has been recognized asan important signal-transduction pathway in regulating terminal differentiation of growth plate chondrocytes. Inhibition of $\beta$-catenin signaling in Col2a1-ICAT transgenic mice results in reduced chondrocyte proliferation and differentiation, delayed formation of the secondary ossific ation center, and reduced skeletal growth (120). Wang et al have shown that T3 promotes growth plate chondrocyte teminal differentiation by inc reasing Wnt-4 expression, $\beta$-catenin accumulation, TCF/LFF transcriptional activity, and expression of the Wnt/ $\beta$-catenin target gene Runx2/cbfal (82). Furthemore, they also have shown that $\mathrm{T3}$ treatment stimulates PI3K/Akt/GSK-3 $\beta$ signaling (105). PI3K and AKt are important signal transducers of IGF-1 signaling. Akt can ina c tivate GSK-3B, a negative regulator of the canonical $W n t / \beta$-catenin pathway (121). The inhibition of PI3K/Akt activity by LY294002 prevents T3-induced Wnt4 expression and $\beta$-catenin activation. These results indicate that $\mathrm{TH}$ promotes growth plate cell differentiation and longitudinal bone growth by activating $\beta$-catenin signaling via modulation of IGF-1/IGFIR signaling through the Wnt and PI3K/Akt pathways. While a number of growth factor signaling pathways have been implicated to play an important role in the $\mathrm{TH}$ regulation of skeletal growth (Figure 3), the extent to which these growth factor signaling pathways contribute to $\mathrm{TH}$ action in vivo remains to be determined

\section{Conclusions}

There is now considerable data in the literature both from mouse genetic studies and human clinical studies involving mutations in genes related to the $\mathrm{TH}$ signaling pathway that demonstrate a key role for $\mathrm{TH}$ in the regulation of skeletal growth. In tems of target cell types for $\mathrm{TH}$ action, while much focus is on chondrocytes, there is also recent evidence that other bone cell types inc luding osteoblasts and osteoc lasts a re also regulated by $\mathrm{TH}$ signaling. In terms of the mechanism for $\mathrm{TH}$ action, studies suggest that $\mathrm{TH}$ regulates a number of key growth factor signaling pathways including IGF-1, Wnt, PTHrP and FG F to regulate skeletal growth. However, the relative contribution of these growth factor signaling pathways in mediating $\mathrm{TH}$ effects on bone in vivo rema in to be determined. The issue of how the various growth factor signaling pathways interact to mediate $\mathrm{TH}$ effects in various target cell types needs to be investigated. Also, studies are needed to address the issue of whether all of the $\mathrm{TH}$ effects on bone cells are mediated via genomic actions of $\mathrm{TH}$ or some of the $\mathrm{TH}$ effects are mediated via non-genomic actions. Future development and application of mice with conditional disnuption of genes involved in $\mathrm{TH}$ signaling pathway in time and space are required to identify the cell-specific mechanisms of $\mathrm{TH}$ action and interaction with various pathways in vivo.

\section{Acknowledgments}

Fina ncial support was received from funding agencies in the United States (NIH grant AR048139 and VA merit review grant). The authors thank Dr. Donna Strong for proof reading the article.

\section{References}

1 Harvey CB, O'Shea PJ, Scott AJ, Robson H, Siebler T, Shalet SM, Samarut J, Chassande O,Williams GR. Molecular mechanisms of thyroid hormone effects on bone growth and function. Mol Genet Metab. 2002;75:17-30.

2 Rivkees SA, Bode HH,Crawford JD. Long-term growth in juvenile acquired hypothyroidism: the failure to achieve normal adult stature. N Engl J Med. 1988;318:599-602.

3 Segni M, Leonardi E, Mazzoncini B, Pucarelli I, Pasquino AM. Special features of Graves' disease in early childhood. Thyroid 1999;9:871-877.

4 Abel ED, Ahima RS, Boers ME, Elmquist JK, Wondisford FE. Critical role for thyroid hormone receptor beta2 in the regulation of paraventricular thyrotropin-releasing hormone neurons. J Clin Invest. 2001;107:1017-1023.

5 Forrest D, Hanebuth E, Smeyne RJ, Everds N, Stewart CL, Wehner JM,Curran T. Recessive resistance to thyroid hormone in mice lacking thyroid hormone receptor beta: evidence for tissue- 
specific modulation of receptor function. EMBO J. 1996;15:30063015 .

6 Bassett JH, Williams GR. Critical role of the hypothalamicpituitary-thyroid axis in bone. Bone. 2008;43:418-426

7 Andersen S, Bruun NH, Pedersen KM, Laurberg P. Biologic variation is important for interpretation of thyroid function tests. Thyroid. 2003;13:1069-1078.

8 Gereben B, Zavacki AM, Ribich S, Kim BW, Huang SA, Simonides WS, Zeold A,Bianco AC. Cellular and molecular basis of deiodinase-regulated thyroid hormone signaling. Endocr Rev. 2008;29:898-938.

9 St Germain DL, Galton VA, Hernandez A. Minireview: Defining the roles of the iodothyronine deiodinases: current concepts and challenges. Endocrinology. 2009;150:1097-1107.

10 Gouveia CH, Christoffolete MA, Zaitune CR, Dora JM, Harney JW, Maia AL, Bianco AC. Type 2 iodothyronine selenodeiodinase is expressed throughout the mouse skeleton and in the MC3T3-E1 mouse osteoblastic cell line during differentiation. Endocrinology. 2005;146:195-200.

11 LeBron BA, Pekary AE, Mirell C, Hahn TJ, Hershman JM. Thyroid hormone 5'-deiodinase activity, nuclear binding, and effects on mitogenesis in UMR-106 osteoblastic osteosarcoma cells. J Bone Miner Res. 1989;4:173-178

12 Williams AJ, Robson H, Kester MH, van Leeuwen JP, Shalet SM, Visser TJ, Williams GR. Iodothyronine deiodinase enzyme activities in bone. Bone. 2008;43:126-134.

13 Visser WE, Friesema EC, Visser TJ. Minireview: thyroid hormone transporters: the knowns and the unknowns. Mol Endocrinol. 2011;25:1-14.

14 Friesema EC, Jansen J, Milici C, Visser TJ. Thyroid hormone transporters. Vitam Horm. 2005;70:137-167.

15 Heuer H, Visser TJ. Minireview: Pathophysiological importance of thyroid hormone transporters. Endocrinology. 2009;150:10781083.

16 Capelo LP, Beber EH, Huang SA, Zorn TM, Bianco AC, Gouveia $\mathrm{CH}$. Deiodinase-mediated thyroid hormone inactivation minimizes thyroid hormone signaling in the early development of fetal skeleton. Bone. 2008;43:921-930.

17 Fraichard A, Chassande O, Plateroti M, Roux JP, Trouillas J, Dehay C, Legrand C, Gauthier K, Kedinger M, Malaval L, Rousset $\mathrm{B}$, Samarut J. The T3R alpha gene encoding a thyroid hormone receptor is essential for post-natal development and thyroid hormone production. EMBO J. 1997;16:4412-4420

18 Williams GR. Cloning and characterization of two novel thyroid hormone receptor beta isoforms. Mol Cell Biol. 2000;20:8329-8342.

19 Koenig RJ, Lazar MA, Hodin RA, Brent GA, Larsen PR, Chin WW, Moore DD. Inhibition of thyroid hormone action by a nonhormone binding c-erbA protein generated by alternative mRNA splicing. Nature. 1989;337:659-661.

20 Plateroti M, Gauthier K, Domon-Dell C, Freund JN, Samarut J, Chassande O. Functional interference between thyroid hormone receptor alpha (TRalpha) and natural truncated TRDeltaalpha isoforms in the control of intestine development. Mol Cell Biol. 2001;21:4761-4772.

21 Forrest D, Sjoberg M, Vennstrom B. Contrasting developmental and tissue-specific expression of alpha and beta thyroid hormone receptor genes. EMBO J. 1990;9:1519-1528.

22 Cheng SY. Isoform-dependent actions of thyroid hormone nuclear receptors: lessons from knockin mutant mice. Steroids. 2005;70: 450-454.

23 Abel ED, Boers ME, Pazos-Moura C, Moura E, Kaulbach H, Zakaria M, Lowell B, Radovick S, Liberman MC, Wondisford F. Divergent roles for thyroid hormone receptor beta isoforms in the endocrine axis and auditory system. J Clin Invest. 1999;104:291300.

24 Forrest D, Reh TA, Rusch A. Neurodevelopmental control by thyroid hormone receptors. Curr Opin Neurobiol. 2002;12:49-56.

25 Cheng SY, Leonard JL, Davis PJ. Molecular aspects of thyroid hormone actions. Endocr Rev. 2010;31:139-170.

26 Bassett JH, Harvey CB, Williams GR. Mechanisms of thyroid hormone receptor-specific nuclear and extra nuclear actions. Mol Cell Endocrinol. 2003;213:1-11.

27 Harvey CB, Williams GR. Mechanism of thyroid hormone action Thyroid. 2002;12:441-446.

28 Kim SW, Ho SC, Hong SJ, Kim KM, So EC, Christoffolete M, Harney JW. A novel mechanism of thyroid hormone-dependent negative regulation by thyroid hormone receptor, nuclear receptor corepressor (NCoR), and GAGA-binding factor on the rat cD44 promoter. J Biol Chem. 2005;280:14545-14555.

29 Farach-Carson MC, Davis PJ. Steroid hormone interactions with target cells: cross talk between membrane and nuclear pathways. J Pharmacol Exp Ther. 2003;307:839-845.

30 Bergh JJ, Lin HY, Lansing L, Mohamed SN, Davis FB, Mousa S, Davis PJ. Integrin alphaVbeta3 contains a cell surface receptor site for thyroid hormone that is linked to activation of mitogenactivated protein kinase and induction of angiogenesis. Endocrinology. 2005;146:2864-2871.

31 Rice DP, Rice R. Locate, condense, differentiate, grow and confront: developmental mechanisms controlling intramembranous bone and suture formation and function. Front Oral Biol. 2008;12: 22-40.

32 Ballock RT, O'Keefe RJ. The biology of the growth plate. J Bone Joint Surg Am. 2003;85-A:715-726.

33 Kronenberg HM. Developmental regulation of the growth plate. Nature. 2003;423:332-336.

34 Bonjour JP, Theintz G, Law F, Slosman D, Rizzoli R. Peak bone mass. Osteoporos Int. 1994;4 Suppl 1:7-13

35 Vestergaard P, Mosekilde L. Fractures in patients with hyperthyroidism and hypothyroidism: a nationwide follow-up study in 16,249 patients. Thyroid. 2002;12:411-419.

36 Vestergaard P, Rejnmark L, Mosekilde L. Influence of hyper- and hypothyroidism, and the effects of treatment with antithyroid drugs and levothyroxine on fracture risk. Calcif Tissue Int. 2005; 77:139-144. 
37 O'Shea PJ, Williams GR. Insight into the physiological actions of thyroid hormone receptors from genetically modified mice. J Endocrinol. 2002;175:553-570.

38 Bassett JH, Williams GR. The skeletal phenotypes of TRalpha and TRbeta mutant mice. J Mol Endocrinol. 2009;42:269-282.

39 Mansouri A, Chowdhury K, Gruss P. Follicular cells of the thyroid gland require Pax8 gene function. Nat Genet. 1998;19:87-90.

40 Friedrichsen S, Christ S, Heuer H, Schafer MK, Mansouri A, Bauer K, Visser TJ. Regulation of iodothyronine deiodinases in the Pax8-/- mouse model of congenital hypothyroidism. Endocrinology. 2003;144:777-784.

41 Beamer WJ, Eicher EM, Maltais LJ, Southard JL. Inherited primary hypothyroidism in mice. Science. 1981;212:61-63.

42 Beamer WG, Cresswell LA. Defective thyroid ontogenesis in fetal hypothyroid (hyt/hyt) mice. Anat Rec. 1982;202:387-393.

43 Gu WX, Du GG, Kopp P, Rentoumis A, Albanese C, Kohn LD, Madison LD, Jameson JL. The thyrotropin (TSH) receptor transmembrane domain mutation (Pro556-Leu) in the hypothyroid hyt/hyt mouse results in plasma membrane targeting but defective TSH binding. Endocrinology. 1995;136:3146-3153.

44 Bassett JH, Williams AJ, Murphy E, Boyde A, Howell PG, Swinhoe R, Archanco M, Flamant F, Samarut J, Costagliola S, Vassart G, Weiss RE, Refetoff S, Williams GR. A lack of thyroid hormones rather than excess thyrotropin causes abnormal skeletal development in hypothyroidism. Mol Endocrinol. 2008;22:501512.

45 Xing W, Govoni KE, Donahue LR, Kesavan C, Wergedal J, Long C, Bassett JH, Gogakos A, Wojcicka A, Williams GR, Mohan S. Genetic evidence that thyroid hormone is indispensable for prepubertal insulin-like growth factor-I expression and bone acquisition in mice. J Bone Miner Res. 2012;27:1067-1079.

46 Marians RC, Ng L, Blair HC, Unger P, Graves PN, Davies TF. Defining thyrotropin-dependent and -independent steps of thyroid hormone synthesis by using thyrotropin receptor-null mice. Proc Natl Acad Sci U S A. 2002;99:15776-15781.

47 Abe E, Marians RC, Yu W, Wu XB, Ando T, Li Y, Iqbal J, Eldeiry L, Rajendren G, Blair HC, Davies TF, Zaidi M. TSH is a negative regulator of skeletal remodeling. Cell. 2003;115:151-162.

48 Bassett JH, Boyde A, Howell PG, Bassett RH, Galliford TM, Archanco M, Evans H, Lawson MA, Croucher P, St Germain DL, Galton VA, Williams GR. Optimal bone strength and mineralization requires the type 2 iodothyronine deiodinase in osteoblasts. Proc Natl Acad Sci U S A. 2010;107:7604-7609.

49 Johnson KR, Marden CC, Ward-Bailey P, Gagnon LH, Bronson RT, Donahue LR. Congenital hypothyroidism, dwarfism, and hearing impairment caused by a missense mutation in the mouse dual oxidase 2 gene, Duox2. Mol Endocrinol. 2007;21:1593-1602.

50 Chassande O, Fraichard A, Gauthier K, Flamant F, Legrand C, Savatier P, Laudet V, Samarut J. Identification of transcripts initiated from an internal promoter in the c-erbA alpha locus that encode inhibitors of retinoic acid receptor-alpha and triiodothyronine receptor activities. Mol Endocrinol. 1997;11:1278-1290.
51 Bassett JH, O'Shea PJ, Sriskantharajah S, Rabier B, Boyde A, Howell PG, Weiss RE, Roux JP, Malaval L, Clement-Lacroix P, Samarut J, Chassande O, Williams GR. Thyroid hormone excess rather than thyrotropin deficiency induces osteoporosis in hyperthyroidism. Mol Endocrinol. 2007;21:1095-1107.

52 Gauthier K, Plateroti M, Harvey CB, Williams GR, Weiss RE, Refetoff S, W ilott JF, Sundin V, Roux JP, Malaval L, Hara M, Samarut J, Chassande O. Genetic analysis reveals different functions for the products of the thyroid hormone receptor alpha locus. Mol Cell Biol. 2001;21:4748-4760.

53 Kaneshige M, Suzuki H, Kaneshige K, Cheng J, Wimbrow H, Barlow C, Willingham MC, Cheng S. A targeted dominant negative mutation of the thyroid hormone alpha 1 receptor causes increased mortality, infertility, and dwarfism in mice. Proc Natl Acad Sci U S A. 2001;98:15095-15100.

54 Chassande O. Do unliganded thyroid hormone receptors have physiological functions? J Mol Endocrinol. 2003;31:9-20.

55 Barnard JC, Williams AJ, Rabier B, Chassande O, Samarut J, Cheng SY, Bassett JH, Williams GR. Thyroid hormones regulate fibroblast growth factor receptor signaling during chondrogenesis. Endocrinology. 2005;146:5568-5580.

56 Bassett JH, Nordstrom K, Boyde A, Howell PG, Kelly S, Vennstrom B, Williams GR. Thyroid status during skeletal development determines adult bone structure and mineralization. Mol Endocrinol. 2007;21:1893-1904.

57 O'Shea PJ, Harvey CB, Suzuki H, Kaneshige M, Kaneshige K, Cheng SY, Williams GR. A thyrotoxic skeletal phenotype of advanced bone formation in mice with resistance to thyroid hormone. Mol Endocrinol. 2003;17:1410-1424.

58 O'Shea PJ, Bassett JH, Sriskantharajah S, Ying H, Cheng SY, Williams GR. Contrasting skeletal phenotypes in mice with an identical mutation targeted to thyroid hormone receptor alpha1 or beta. Mol Endocrinol. 2005;19:3045-3059.

59 Kaneshige M, Kaneshige K, Zhu X, Dace A, Garrett L, Carter TA, Kazlauskaite R, Pankratz DG, Wynshaw-Boris A, Refetoff S, Weintraub B, Willingham MC, Barlow C, Cheng S. Mice with a targeted mutation in the thyroid hormone beta receptor gene exhibit impaired growth and resistance to thyroid hormone. Proc Natl Acad Sci U S A. 2000;97:13209-13214.

60 Boersma B, Otten BJ, Stoelinga GB, Wit JM. Catch-up growth after prolonged hypothyroidism. Eur J Pediatr. 1996;155:362-367.

61 Segni M, Gorman CA. The aftermath of childhood hyperthyroidism. J Pediatr Endocrinol Metab. 2001;14 Suppl 5:1277-1282; discussion 1297-1298.

62 Papadimitriou A, Papadimitriou DT, Papadopoulou A, Nicolaidou P, Fretzayas A. Low TSH levels are not associated with osteoporosis in childhood. Eur J Endocrinol. 2007;157:221-223.

63 Refetoff S. Resistance to thyrotropin. J Endocrinol Invest. 2003;26: 770-779.

64 Persani L, Calebiro D, Cordella D, Weber G, Gelmini G, Libri D, de Filippis T, Bonomi M. Genetics and phenomics of hypothyroidism due to TSH resistance. Mol Cell Endocrinol. 2010;322 
72-82.

65 Gozu HI, Lublinghoff J, Bircan R, Paschke R. Genetics and phenomics of inherited and sporadic non-autoimmune hyperthyroidism. Mol Cell Endocrinol. 2010;322:125-134.

66 Refetoff S, Dumitrescu AM. Syndromes of reduced sensitivity to thyroid hormone: genetic defects in hormone receptors, cell transporters and deiodination. Best Pract Res Clin Endocrinol Metab. 2007;21:277-305.

67 Refetoff S, DeWind LT, DeGroot LJ. Familial syndrome combining deaf-mutism, stuppled epiphyses, goiter and abnormally high PBI: possible target organ refractoriness to thyroid hormone. J Clin Endocrinol Metab. 1967;27:279-294.

68 Weiss RE, Refetoff S. Treatment of resistance to thyroid hormoneprimum non nocere. J Clin Endocrinol Metab. 1999;84:401-404.

69 Bochukova E, Schoenmakers N, Agostini M, Schoenmakers E, Rajanayagam O, Keogh JM, Henning E, Reinemund J, Gevers E, Sarri M, Downes K, Offiah A, Albanese A, Halsall D, Schwabe JW, Bain M, Lindley K, Muntoni F, Vargha-Khadem F, Dattani M, Farooqi IS, Gurnell M, Chatterjee K. A mutation in the thyroid hormone receptor alpha gene. N Engl J Med. 2012;366:243-249.

70 van Mullem A, van Heerebeek R, Chrysis D, Visser E, Medici M, Andrikoula M, Tsatsoulis A, Peeters R, Visser TJ. Clinical phenotype and mutant TRalpha1. N Engl J Med. 2012;366:1451-1453.

71 Ferrara AM, Onigata K, Ercan O, Woodhead H, Weiss RE, Refetoff $\mathrm{S}$. Homozygous thyroid hormone receptor beta-gene mutations in resistance to thyroid hormone: three new cases and review of the literature. J Clin Endocrinol Metab. 2012;97:1328-1336.

72 Friesema EC, Grueters A, Biebermann H, Krude H, von Moers A, Reeser M, Barrett TG, Mancilla EE, Svensson J, Kester MH, Kuiper GG, Balkassmi S, Uitterlinden AG, Koehrle J, Rodien P, Halestrap AP, Visser TJ. Association between mutations in a thyroid hormone transporter and severe X-linked psychomotor retardation. Lancet. 2004;364:1435-1437.

73 Dumitrescu AM, Liao XH, Best TB, Brockmann K, Refetoff S. A novel syndrome combining thyroid and neurological abnormalities is associated with mutations in a monocarboxylate transporter gene. Am J Hum Genet. 2004;74:168-175.

74 Dumitrescu AM, Liao XH, Abdullah MS, Lado-Abeal J, Majed FA, Moeller LC, Boran G, Schomburg L, Weiss RE, Refetoff S. Mutations in SECISBP2 result in abnormal thyroid hormone metabolism. Nat Genet. 2005;37:1247-1252.

75 Robson H, Siebler T, Stevens DA, Shalet SM, Williams GR. Thyroid hormone acts directly on growth plate chondrocytes to promote hypertrophic differentiation and inhibit clonal expansion and cell proliferation. Endocrinology. 2000;141:3887-3897.

76 Miura M, Tanaka K, Komatsu Y, Suda M, Yasoda A, Sakuma Y, Ozasa A, Nakao K. Thyroid hormones promote chondrocyte differentiation in mouse ATDC5 cells and stimulate endochondral ossification in fetal mouse tibias through iodothyronine deiodinases in the growth plate. J Bone Miner Res. 2002;17:443454.

77 Ishikawa Y, Genge BR, Wuthier RE, Wu LN. Thyroid hormone inhibits growth and stimulates terminal differentiation of epiphyseal growth plate chondrocytes. J Bone Miner Res. 1998;13:13981411.

78 Himeno M, Enomoto H, Liu W, Ishizeki K, Nomura S, Kitamura Y,Komori T. Impaired vascular invasion of Cbfa1-deficient cartilage engrafted in the spleen. J Bone Miner Res. 2002;17:1297-1305.

79 Mello MA,Tuan RS. Effects of TGF-beta1 and triiodothyronine on cartilage maturation: in vitro analysis using long-term highdensity micromass cultures of chick embryonic limb mesenchymal cells. J Orthop Res. 2006;24:2095-2105.

80 Makihira S, Yan W, Murakami H, Furukawa M, Kawai T, Nikawa H, Yoshida E, Hamada T, Okada Y, Kato Y. Thyroid hormone enhances aggrecanase-2/ADAM-TS5 expression and proteoglycan degradation in growth plate cartilage. Endocrinology. 2003;144:2480-2488.

81 Pereira RC, Jorgetti V, Canalis E. Triiodothyronine induces collagenase-3 and gelatinase B expression in murine osteoblasts. Am J Physiol. 1999;277:E496-E504.

82 Wang L, Shao YY, Ballock RT. Thyroid hormone interacts with the Wnt/beta-catenin signaling pathway in the terminal differentiation of growth plate chondrocytes. J Bone Miner Res. 2007;22: 1988-1995.

83 Stevens DA, Hasserjian RP, Robson H, Siebler T, Shalet SM, Williams GR. Thyroid hormones regulate hypertrophic chondrocyte differentiation and expression of parathyroid hormonerelated peptide and its receptor during endochondral bone formation. J Bone Miner Res. 2000;15:2431-2442.

84 Gouveia $\mathrm{CH}$, Schultz JJ, Bianco AC, Brent GA. Thyroid hormone stimulation of osteocalcin gene expression in ROS $17 / 2.8$ cells is mediated by transcriptional and post-transcriptional mechanisms. J Endocrinol. 2001;170:667-675.

85 Varga F, Rumpler M, Zoehrer R, Turecek C, Spitzer S, Thaler R, Paschalis EP, Klaushofer K. T3 affects expression of collagen I and collagen cross-linking in bone cell cultures. Biochem Biophys Res Commun. 2010;402:180-185.

86 Varga F, Rumpler M, Luegmayr E, Fratzl-Zelman N, Glantschnig $\mathrm{H}$, Klaushofer K. Triiodothyronine, a regulator of osteoblastic differentiation: depression of histone $\mathrm{H} 4$, attenuation of c-fos/ c-jun, and induction of osteocalcin expression. Calcif Tissue Int. 1997;61:404-411.

87 Banovac K, Koren E. Triiodothyronine stimulates the release of membrane-bound alkaline phosphatase in osteoblastic cells. Calcif Tissue Int. 2000;67:460-465.

88 Stevens DA, Harvey CB, Scott AJ, O'Shea PJ, Barnard JC, Williams AJ, Brady G, Samarut J, Chassande O, Williams GR. Thyroid hormone activates fibroblast growth factor receptor-1 in bone. Mol Endocrinol. 2003;17:1751-1766.

89 Gu WX, Stern PH, Madison LD, Du GG. Mutual up-regulation of thyroid hormone and parathyroid hormone receptors in rat osteoblastic osteosarcoma 17/2.8 cells. Endocrinology. 2001;142:157164.

90 Huang BK, Golden LA, Tarjan G, Madison LD, Stern PH. Insulin- 
like growth factor I production is essential for anabolic effects of thyroid hormone in osteoblasts. J Bone Miner Res. 2000;15:188197.

91 Linares GR, Xing W, Burghardt H, Baumgartner B, Chen ST, Ricart W, Fernandez-Real JM, Zorzano A, Mohan S. Role of diabetes- and obesity-related protein in the regulation of osteoblast differentiation. Am J Physiol Endocrinol Metab. 2011;301: E40-E48.

92 Klaushofer K, Hoffmann O, Gleispach H, Leis HJ, Czerwenka E, Koller K, Peterlik M. Bone-resorbing activity of thyroid hormones is related to prostaglandin production in cultured neonatal mouse calvaria. J Bone Miner Res. 1989;4:305-312.

93 Mundy GR, Shapiro JL, Bandelin JG, Canalis EM, Raisz LG. Direct stimulation of bone resorption by thyroid hormones. J Clin Invest. 1976;58:529-534.

94 Hoffmann O, Klaushofer K, Koller K, Peterlik M, Mavreas T, Stern P. Indomethacin inhibits thrombin-, but not thyroxin-stimulated resorption of fetal rat limb bones. Prostaglandins. 1986;31:601-608.

95 Allain TJ, Chambers TJ, Flanagan AM, McGregor AM. Triiodothyronine stimulates rat osteoclastic bone resorption by an indirect effect. J Endocrinol. 1992;133:327-331.

96 Britto JM, Fenton AJ, Holloway WR, Nicholson GC. Osteoblasts mediate thyroid hormone stimulation of osteoclastic bone resorption. Endocrinology. 1994;134:169-176.

97 Siddiqi A, Burrin JM, Wood DF, Monson JP. Tri-iodothyronine regulates the production of interleukin- 6 and interleukin- 8 in human bone marrow stromal and osteoblast-like cells. J Endocrinol. 1998;157:453-461.

98 Miura M, Tanaka K, Komatsu Y, Suda M, Yasoda A, Sakuma Y, Ozasa A, Nakao K. A novel interaction between thyroid hormones and $1,25(\mathrm{OH})(2) \mathrm{D}(3)$ in osteoclast formation. Biochem Biophys Res Commun. 2002;291:987-994.

99 Abu EO, Bord S, Horner A, Chatterjee VK, Compston JE. The expression of thyroid hormone receptors in human bone. Bone. 1997;21:137-142.

100 Govoni KE, Wergedal JE, Florin L, Angel P, Baylink DJ, Mohan S. Conditional deletion of insulin-like growth factor-I in collagen type 1alpha2-expressing cells results in postnatal lethality and a dramatic reduction in bone accretion. Endocrinology. 2007;148: 5706-5715.

101 Mohan S, Richman C, Guo R, Amaar Y, Donahue LR, Wergedal J, Baylink DJ. Insulin-like growth factor regulates peak bone mineral density in mice by both growth hormone-dependent and -independent mechanisms. Endocrinology. 2003;144:929-936.

102 Zhang M, Xuan S, Bouxsein ML, von Stechow D, Akeno N, Faugere MC, Malluche H, Zhao G, Rosen CJ, Efstratiadis A, Clemens TL. Osteoblast-specific knockout of the insulin-like growth factor (IGF) receptor gene reveals an essential role of IGF signaling in bone matrix mineralization. J Biol Chem. 2002;277:44005-44012.

103 van der Eerden BC, Karperien M, W t JM. Systemic and local regulation of the growth plate. Endocr Rev. 2003;24:782-801.
104 Wang Y, Nishida S, Sakata T, Elalieh HZ, Chang W, Halloran BP, Doty SB, Bikle DD. Insulin-like growth factor-I is essential for embryonic bone development. Endocrinology. 2006;147:47534761.

105 Wang L, Shao YY, Ballock RT. Thyroid hormone-mediated growth and differentiation of growth plate chondrocytes involves IGF-1 modulation of beta-catenin signaling. J Bone Miner Res. 2010;25:1138-1146.

106 Richman C, Kutilek S, Miyakoshi N, Srivastava AK, Beamer WG, Donahue LR, Rosen CJ, Wergedal JE, Baylink DJ, Mohan S. Postnatal and pubertal skeletal changes contribute predominantly to the differences in peak bone density between $\mathrm{C} 3 \mathrm{H} / \mathrm{HeJ}$ and C57BL/6J mice. J Bone Miner Res. 2001;16:386-397.

107 Lakatos P, Caplice MD, Khanna V, Stern PH. Thyroid hormones increase insulin-like growth factor I content in the medium of rat bone tissue. J Bone Miner Res. 1993;8:1475-1481.

108 Thorngren KG, Hansson LI. Effect of thyroxine and growth hormone on longitudinal bone growth in the hypophysectomized rat. Acta Endocrinol (Copenh). 1973;74:24-40.

109 Lewinson D, Bialik GM, Hochberg Z. Differential effects of hypothyroidism on the cartilage and the osteogenic process in the mandibular condyle: recovery by growth hormone and thyroxine. Endocrinology. 1994;135:1504-1510.

110 Ohlsson C, Isgaard J, Tornell J, Nilsson A, Isaksson OG, Lindahl A. Endocrine regulation of longitudinal bone growth. Acta Paediatr Suppl. 1993;82 Suppl 391:33-40; discussion 41.

111 Gauthier K, Chassande O, Plateroti M, Roux JP, Legrand C, Pain B, Rousset B, Weiss R, Trouillas J, Samarut J. Different functions for the thyroid hormone receptors TRalpha and TRbeta in the control of thyroid hormone production and post-natal development. EMBO J. 1999;18:623-631.

112 King RA, Smith RM, Meller DJ, Dahlenburg GW, Lineham JD. Effect of growth hormone on growth and myelination in the neonatal hypothyroid rat. J Endocrinol. 1988;119:117-125.

113 Vortkamp A, Lee K, Lanske B, Segre GV, Kronenberg HM, Tabin CJ. Regulation of rate of cartilage differentiation by Indian hedgehog and PTH-related protein. Science. 1996;273:613-622.

114 Dentice M, Bandyopadhyay A, Gereben B, Callebaut I, Christoffolete MA, Kim BW, Nissim S, Mornon JP, Zavacki AM, Zeold A, Capelo LP, Curcio-Morelli C, Ribeiro R, Harney JW, Tabin CJ, Bianco AC. The Hedgehog-inducible ubiquitin ligase subunit WSB-1 modulates thyroid hormone activation and PTHrP secretion in the developing growth plate. Nat Cell Biol. 2005;7:698-705.

115 Ornitz DM, Marie PJ. FGF signaling pathways in endochondral and intramembranous bone development and human genetic disease. Genes Dev. 2002;16:1446-1465.

116 Coumoul X, Deng CX. Roles of FGF receptors in mammalian development and congenital diseases. Birth Defects Res C Embryo Today. 2003;69:286-304.

117 Deng C, Wynshaw-Boris A, Zhou F, Kuo A, Leder P. Fibroblast growth factor receptor 3 is a negative regulator of bone growth. Cell. 1996;84:911-921. 
118 Colvin JS, Bohne BA, Harding GW , McEwen DG, Ornitz DM. Skeletal overgrowth and deafness in mice lacking fibroblast growth factor receptor 3. Nat Genet. 1996;12:390-397.

119 Minina E, Kreschel C, Naski MC, Ornitz DM, Vortkamp A. Interaction of FGF, Ihh/Pthlh, and BMP signaling integrates chondrocyte proliferation and hypertrophic differentiation. Dev Cell. 2002;3:439-449.

120 Chen M, Zhu M, Awad H, Li TF, Sheu TJ, Boyce BF, Chen D, O'Keefe RJ. Inhibition of beta-catenin signaling causes defects in postnatal cartilage development. J Cell Sci. 2008;121:1455-1465.

121 Brazil DP, Yang ZZ, Hemmings BA. Advances in protein kinase B signalling: AKTion on multiple fronts. Trends Biochem Sci. 2004;29:233-242.

122 Wikstrom L, Johansson C, Salto C, Barlow C, Campos Barros A, Baas F, Forrest D, Thoren P, Vennstrom B. Abnormal heart rate and body temperature in mice lacking thyroid hormone receptor alpha 1. EMBO J. 1998;17:455-461.
123 Salto C, Kindblom JM, Johansson C, Wang Z, Gullberg $\mathrm{H}$ Nordstrom K, Mansen A, Ohlsson C, Thoren P, Forrest D, Vennstrom B. Ablation of TRalpha2 and a concomitant overexpression of alpha1 yields a mixed hypo- and hyperthyroid phenotype in mice. Mol Endocrinol. 2001;15:2115-2128.

124 Gothe S, Wang Z, Ng L, Kindblom JM, Barros AC, Ohlsson C, Vennstrom B, Forrest D. Mice devoid of all known thyroid hormone receptors are viable but exhibit disorders of the pituitary-thyroid axis, growth, and bone maturation. Genes Dev. 1999;13:1329-1341.

$125 \mathrm{Ng}$ L, Hurley JB, Dierks B, Srinivas M, Salto C, Vennstrom B, Reh TA, Forrest D. A thyroid hormone receptor that is required for the development of green cone photoreceptors. Nat Genet. 2001;27:94-98.

126 Weiss RE. "They have ears but do not hear" (Psalms 135:17) non-thyroid hormone receptor beta (non-TRbeta) resistance to thyroid hormone. Thyroid. 2008;18:3-5. 